\title{
Sowing date of palisadegrass intercropped with grain sorghum and soybean yield in succession
}

\author{
Danyllo Santos Dias', Renan Caldas Umburanas ${ }^{*}$, Darly Geraldo de Sena Junior ${ }^{2}$
}

'University of São Paulo, Piracicaba, Brazi

2 Federal University of Goiás, Brazil

*Corresponding author, e-mail: renan.umburanas@gmail.com

\begin{abstract}
The use of intercropping sorghum-palisadegrass for grain and straw production has become an advantageous cultivation option, can provide improvements in physical and chemical soil properties, maximizes production and income to the growers. There are still many management gaps to be improved in this intercropping in order that grower has the best outcome. Considering this, the objective of this study was to evaluate different sowing dates of palisadegrass in relation to sorghum, and evaluate the yield of soybean cultivated in succession. Palisadegrass was sown in monocrop and also between the lines of sorghum at different times $(0,15$ and 25 days after sowing sorghum), as well the sorghum in monocrop. Soybeans were grown in succession on the straw of the mentioned treatments. It was evaluated biomass production and grain yield. Sowing palisadegrass and sorghum on the same day reduced sorghum grain yield and the palisadegrass biomass production. However, if palisadegrass are sowed 15 days after sorghum sowing, did not reduce the sorghum grain yield. Also, if the producer aims to produce sorghum grains, it is better to delay the sowing of palisadegrass in relation to sorghum. Although, if the producer aims to produce residual dry biomass, it is better to sow palisadegrass on the same day as sorghum or monocrop palisadegrass. Soybean yield did not differ among treatments when grown on different straws in the first year of cultivation.
\end{abstract}

Keywords: brachiaria, crop-livestock integration, no-tillage, Sorghum bicolor, Urochloa ruziziensis

\section{Introduction}

In order to agriculture continue being developed, and that higher yields are achieved in the future, it is important that the management meets the conservation principles of no-tillage system, which consist in maintain the straw on the soil surface and direct sowing on straw without soil disturbance.

However, there are difficulties in implementing no-tillage system in regions with dry season, such as the brazilian cerrado, that begins in mid-April and lasts until mid-October (Pacheco et al., 2008), followed by a rainy season with high temperatures causing rapid decomposition of ground straw cover.

The Palisadegrass (Urochloaruziziensis) has been cultivated in order to increase the amount of straw on the ground, and can contribute to the implementation and maintenance of no-tillage system, agricultural practice with benefits already consolidated by brazilian agriculture (Santos et al., 2008)

The cultivation of sorghum (Sorghum bicolor (L.) Moench) is also an alternative for places where the growing season of winter corn ended or there is an uneven distribution of rainfall. Sorghum has adaptability to various environmental conditions, including unfavourable conditions for most of the crops, for example, irregular rain and high temperature (Silva et 
al., 2010). Furthermore, it is a plant with a high biomass production rate, which can be grown in various environmental conditions and practically the entire brazilian territory (Freitas et al., 2012).

Sorghum is more efficient than corn and wheat to convert water to dry biomass and presents morphological and biochemical mechanisms that confer tolerance to drought (Magalhães et al., 2009). Thus, this culture has greater flexibility in sowing date and can be grown in the second season under the conditions of the Cerrado biome in Brazil (Horvathy Neto et al., 2014).

The sorghum-palisadegrass intercropping is a new practice that has been widespread among growers in the brazilian cerrado, and can serve two purposes: the first is to increase the biomass production per area for ground cover; the second is the formation forage for feed after harvest of grain culture, meeting the principles of crop-livestock integration.

There are still many management gaps to be improved in this intercropping, in order that grower has the best outcome and conditions to manage the area under no-tillage system. Considering this, the objective of this study was to evaluate different sowing dates of palisadegrass in relation to sorghum, and evaluate the yield of the soybean crop cultivated in succession.

\section{Material and methods}

Field experiments were conducted in 2011/12 and 2012/13 seasons in Latossolo Vermelho distroférrico (Embrapa, 2013a), Oxisoil Eutroperox (Burt \& Soil Survey Staff, 2014) at Universidade Federal de Goiás (UFG), in Jataí, Goiás, Brazil (17053' S, 5243' W, altitude 670 m). The climate is $\mathrm{CW}$ type according to Köppen classification. The area where the experiment was conducted was occupied for eight years by the succession soybean/sorghum in notillage system. In Figure 1 is presented the data of precipitation and maximum and minimum temperatures during the experiment (Inmet, 2016).

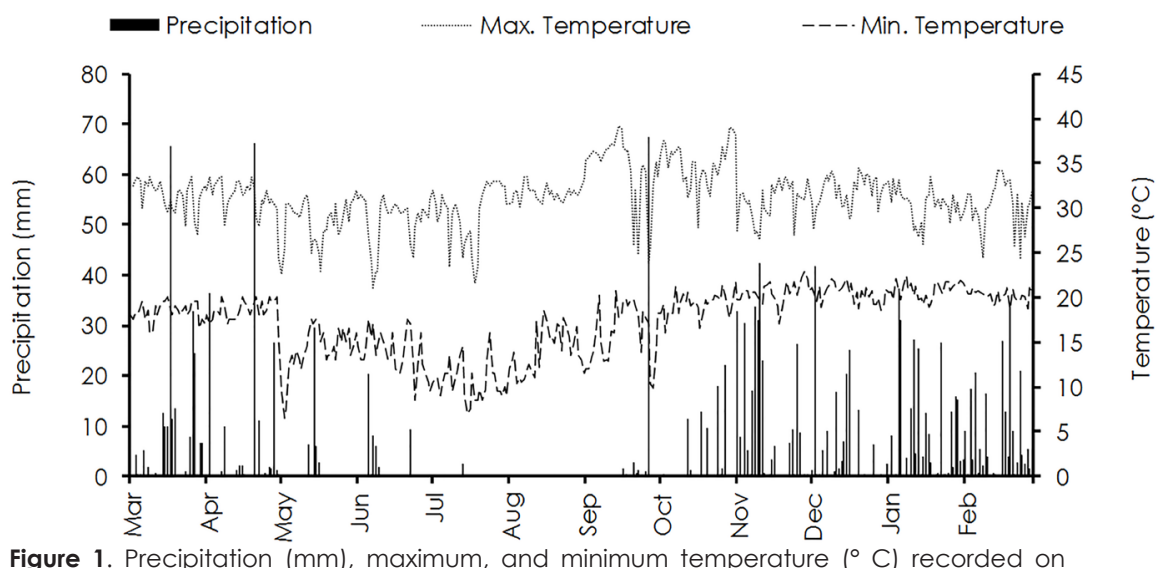

Figure 1. Precipitation (mm), maximum, and minimum temperature ( ${ }^{\circ}$ C) recorded on $2011 / 12$, and 2012/13 seasons in Jataí, Goiás, Brazil.

The chemical analysis of the soil arable layer $(0-20 \mathrm{~cm})$ showed: $\mathrm{pH}\left(\mathrm{CaCl}_{2}\right): 4.8$; organic

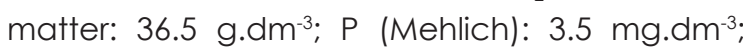
$\mathrm{H}+\mathrm{Al}: 6.6 \mathrm{cmol}_{\mathrm{c}} \cdot \mathrm{dm}^{-3} ; \mathrm{K}, \mathrm{Ca}, \mathrm{Mg}$, and Al: 0.08 ; 2.0; 0.8 , and $0.1 \mathrm{cmol}_{\mathrm{c}} \mathrm{dm}^{-3}$, respectively; cation exchange capacity: $9.5 \mathrm{cmol}_{c} \cdot \mathrm{dm}^{-3}$, and base saturation: $30.5 \%$.

The study consisted of two experiments: the first evaluated the yield and dry biomass production of sorghum and palisadegrass (U. ruziziensis), associated or not with different sowing dates of palisadegrass; the second experiment evaluated soybean yield subsequently grown on the straw of different treatments from first experiment.

The water balance of the experiment period was determined using the method of Thornthwaite \& Mather (1955) using a worksheet elaborated by Rolim et al. (1998).

Experiment 1

The experiment used a randomized block design, with seven treatments and four replications. The treatments were: (i) Sorghum monocrop; (ii) Sorghum and palisadegrass sown on the same day; (iii) Sorghum and palisadegrass sown 15 days after sorghum (DAS); (iv) Sorghum 
and palisadegrass sown 25 DAS; (v) Palisadegrass monocrop sown 0 DAS; (vi) Palisadegrass monocrop sown 15 DAS; (vii) Palisadegrass monocrop sown 25 DAS. Each plot consists of five rows of plants with a length of $6 \mathrm{~m}$ and row spacing of $0.45 \mathrm{~m}$. The three central rows were considered the useful area, except for $0.5 \mathrm{~m}$ from each edge. The harvest of dry biomass was done in $5.4 \mathrm{~m}^{2}$ from useful area.

\section{Glyphosate [N-(phosphonomethyl)} glycine] was applied seven days before sowing, at a dose of $1.42 \mathrm{~kg} \mathrm{ha}^{-1}$ of active ingredient. Sorghum variety used was the hybrid "1G100" - Dow Agrosciences brand, super-early cycle, low size, resistant to lodging and purpose for grain production. Sowing was carried out on March 13, in 2012 season targeting a seeding rate of 180,000 plants. ha ${ }^{-1}$. The palisadegrass (U. ruziziensis) was sown between sorghum rows on March 13 (0 DAS), March 28 (15 DAS), April 12 (25 DAS) in the 2012/2013 season, with a seeding rate of $12 \mathrm{~kg} \mathrm{ha}^{-1}$ seed. The sowing depth of sorghum and palisadegrass was $5 \mathrm{~cm}$.

The fertilizer applied below the sowing furrow was $7 \mathrm{~kg} \cdot \mathrm{ha}^{-1}$ of $\mathrm{N}, 70 \mathrm{~kg} \cdot \mathrm{ha}^{-1}$ of $\mathrm{P}_{2} \mathrm{O}_{5}$ and $63 \mathrm{~kg} \cdot \mathrm{ha}^{-1}$ of $\mathrm{K}_{2} \mathrm{O}$. At 30 days after sorghum emergence, was held topdressing with $40 \mathrm{~kg} \cdot \mathrm{ha}^{-1}$ of $\mathrm{N}$ in all treatments. Sorghum plants present in $5.4 \mathrm{~m}^{2}$ of each plot useful area were harvested near the soil surface at physiological maturity $(114$ DAS) to determine total dry biomass and grain yield. The grains from each plot was cleaned, weighed, and moisture measured by dielectric sealer. Reported yield was adjusted to $130 \mathrm{~g}^{\mathrm{kg}}{ }^{-1}$ moisture content.

Palisadegrass plants presents in $2 \mathrm{~m}^{2}$ of plots useful area were collected near the soil surface at 5 and 52 days after the harvest of sorghum, first and second cut respectively, to determine total dry biomass. Collected samples were placed in a forced-air drier at $70^{\circ} \mathrm{C}$ for 48 hours.

Experiment II

The experiment II used the same design of experiment I. The soybean crop was sown on the straw of the seven previous treatments. It was used the cultivar "Anta 82" - TMG brand, maturity group 7.4, semi-determinate growth habit, resistant to lodging and medium size. Seeds were inoculated before sowing with Bradyrhizobium japonicum through a peat inoculant targeting a concentration of 1.2 million viable cells per seed (Embrapa, 2013b).

Sowing was held on October 30 in the $2012 / 13$ season, aiming a seeding rate of 450,000 plants $\mathrm{ha}^{-1}$. The fertilizer applied below the sowing furrow was $120 \mathrm{~kg}^{-h^{-1}}$ of $\mathrm{P}_{2} \mathrm{O}_{5^{\prime}}$ and $80 \mathrm{~kg} \cdot \mathrm{ha}^{-1}$ of $\mathrm{K}_{2} \mathrm{O}$. The crop treatment and management were aiming to maximum yield.

Soybean plants present in $5.4 \mathrm{~m}^{2}$ of useful area of each plot were harvested near the soil surface at physiological maturity (115 DAS) to determine the plant height, grain weight, grain number and yield. Plant height was measured from plant base to last node. The grain moisture was measured and adjusted in the same method as in Experiment I.

Statistical analysis

The Shapiro-Wilk test indicated normality for the data evaluated. The results were submitted to analysis of variance, and when significant, the data were submitted to Tukey test at $5 \%$ probability.

\section{Results and discussion}

During the months of May to midSeptember, the crops were submitted to water stress conditions, in which the actual evapotranspiration was below potential evapotranspiration (Figure $2 a$ and $2 b$ ). This year was a typical year, with dry season among May and September.

Experiment I

There was no water stress during the establishment of sorghum and brachiaria (Figure $2 a$ and $2 b$ ), a critical period in relation to the need for water (Lima et al., 2011). The residual dry biomass of sorghum reduced when grown in intercropping with palisadegrass, however the delay in palisadegrass sowing led sorghum increase production of dry biomass (Table 1). Other studies found no difference for sorghum dry matter grown in intercropping with $U$. brizantha cv. Marandu, sown on the same date (Crusciol et al., 2011; Mateus et al., 2011). This difference can be explained by the installation method of palisadegrass, in these works it was sown in the fertilizer slot of sower machine, while in this 

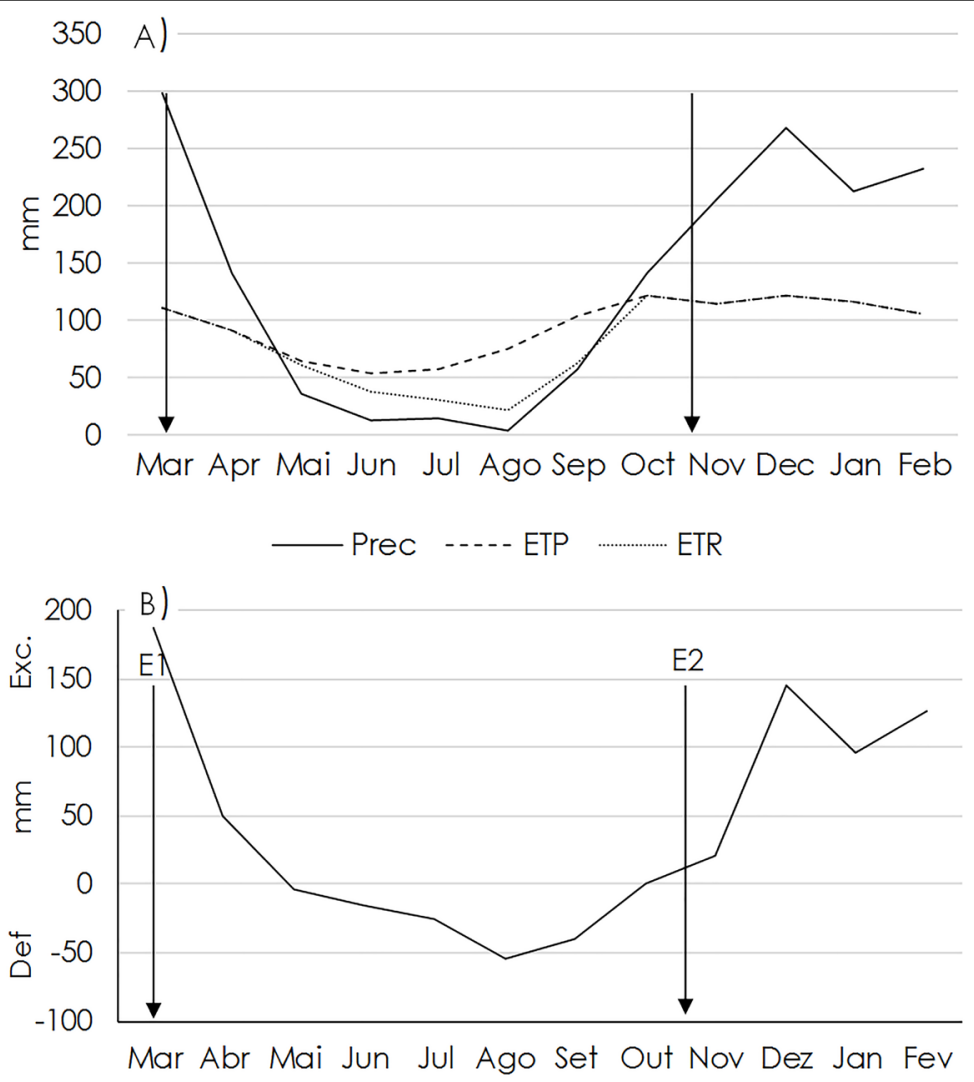

Figure 2. (a) Normal water balance, with precipitation (Prec), potential evapotranspiration (ETP), real evapotranspiration (ETR); (b) Water balance extract. El: Sowing date of experiment I; E2: Sowing date of experiment II.

experiment was sown between the sorghum rows.

Palisadegrass implementation can occur in various ways, with seeding the forage between the rows of soybean crop (Silva et al., 2006), oversowing (Pacheco et al., 2008), grown in row and between row of cultivated corn in the first season (Borghi et al., 2008), between the rows of corn grown in the second season (Alves et al., 2013), and in row and between rows of sorghum crop (Almeida et al., 2012; Silva et al., 2013).

When palisadegrass was sown on the same day as sorghum, sorghum grain yield reduced, but there was no difference in yield among the others treatments (Table 1). Yield means obtained in this study were higher than the brazilian national average, which is 2,844 kg.ha-1 (Conab, 2016).

In a study that evaluated the maizecommon bean intercropping, it was verified that in the row of beans near the maize line there was less photosynthetic active radiation, an important factor to maintain the yield of the main crop and to suppress the intercropped culture (Munz et al.,

Table 1. Sorghum Residual dry biomass (SRB), sorghum grain yield (SY), dry biomass from first cut of palisadegrass 5 days after sorghum harvest (UDB 1), dry biomass from second cut of palisadegrass 52 days after sorghum harvest (UDB2), and total residual dry biomass (TDB) in different treatments of sorghum-palisadegrass intercropping in Jataí, Goiás State, Brazil

\begin{tabular}{|c|c|c|c|c|c|}
\hline \multirow{2}{*}{ Treatment } & SRB & SY & UDB I & UDB2 & $\mathrm{TDB}^{1}$ \\
\hline & \multicolumn{5}{|c|}{ 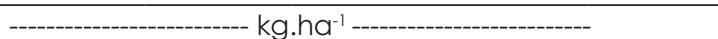 } \\
\hline Sorghum monocrop & $3,079 a$ & 3,136 a & 0 & 0 & $3,079 \mathrm{c}$ \\
\hline Sorghum + Palisadegrass (0 DAS²) & $1,644 \mathrm{C}$ & $2,382 \mathrm{~b}$ & $3,136 \mathrm{C}$ & $2,748 \mathrm{~b}$ & $4,780 \mathrm{bc}$ \\
\hline Sorghum + Palisadegrass (15 DAS) & $2,228 \mathrm{bc}$ & $3,154 a$ & $553 d$ & $1,564 \mathrm{~b}$ & $2,781 \mathrm{C}$ \\
\hline Sorghum + Palisadegrass (25 DAS) & $2,472 a b$ & $3,344 a$ & $170 \mathrm{~d}$ & $1,248 b$ & $2,642 \mathrm{c}$ \\
\hline Palisadegrass monocrop (0 DAS) & 0 & 0 & $10,555 \mathrm{a}$ & $7,213 a$ & $10,555 a$ \\
\hline Palisadegrass monocrop(15 DAS) & 0 & 0 & 7,405 b & $6,573 a$ & $7,405 \mathrm{~b}$ \\
\hline Palisadegrass monocrop (25 DAS) & 0 & 0 & $4,469 \mathrm{C}$ & $5,388 a$ & $4,469 \mathrm{C}$ \\
\hline
\end{tabular}


2014).

The development of palisadegrass is impaired when the plant is intercropped compared to palisadegrass monocrop. The development of palisadegrass (U. ruziziensis) is reduced by approximately $40 \%$ when grown intercropped compared to monocrop palisadegrass (Baldé et al., 2011). Palisadegrass plants (Urochloa brizantha) in association with maize may exhibit less tillering, stunted growth and lower dry matter in relation to monocrop palisadegrass (Araujo et al., 2011).

The intercropping reduced sorghum yield only when sowing of the two species was on the same date. However, with the delay of palisadegrass sowing in relation to sorghum there was no difference in sorghum grain yield compared to monocrop sorghum. Similar results were obtained in sorghum intercropped with $U$. brizantha, which reduced yield when compared sorghum in monoculture (Silva et al., 2013). The delay in palisadegrass sowing in relation to sorghum minimizes competition between these species for the environment, allowing sorghum shows similar yield when compared to monocrop sorghum.

The palisadegrass dry biomass reduced when intercropped with sorghum in relation to palisadegrass monocrop (Table 1). The delay in palisadegrass sowing on 15 and 25 days after sorghum sowing significantly reduced the palisadegrass dry biomass.

With the increased production of palisadegrass dry biomass, sorghum grain yield reduced. The best management strategy will depend on the intercropping purpose. For higher sorghum grain yield, palisadegrass should be sown 15 or 25 days after sowing sorghum, but with lower production of palisadegrass dry biomass. When the objective is to increase palisadegrass dry biomass in detriment of the sorghum grain yield, the grower can choose the same date for sowing palisadegrass and sorghum.

The palisadegrass was sown between the sorghum sowing lines at $5 \mathrm{~cm}$ depth. A better refinement of management strategy sorghumpalisadegrass intercropping is necessary, for example, evaluation of plant density for both cultures and sowing depth for palisadegrass.
Perhaps sow palisadegrass on the same day of sorghum sowing, with a greater depth for the palisadegrass seeds may reduce competition between these cultures.

The total residual dry biomass, which considers residual dry biomass of sorghum with the first cutting palisadegrass, differ among treatments (Table 1). The largest production of dry biomass was in monocrop palisadegrass. With the delay of sowing palisadegrass monocrop in 15 and 25 days, the production of dry biomass was reduced, this occurred because these treatments have less time to develop and perform photosynthesis.

The intercropping sorghum-palisadegrass produced more dry biomass compared to monocrop sorghum. There is a report that in sorghum-palisadegrass intercropping produced 8 ton.ha' ${ }^{-1}$ of dry biomass, 94 days after sorghum harvest and first cut of palisadegrass (Crusciol et al., 2011). In this work the highest production of dry biomass obtained was 4,7 ton.ha' ${ }^{-1}$, this difference can be explained by the production environment of this experiment, which was more exposed to thermal and water stress.

The treatment with lower production residual dry biomass was the monocrop sorghum, which produced 3 ton.ha ${ }^{-1}$, and the higher production was the monocrop palisadegrass, which produced 10 ton. ha $^{-1}$.

In general, when the grower aims sorghum grains production, the intercropping with palisadegrass sowed after the sorghum crop establishment proves to be a viable option because it does not affect sorghum grain yield and promotes a higher amount of residual biomass to soil, which contributes to conservation practices such as no-tillage system.

Experiment II

There was no effect of treatments residual biomass on soybean attributes evaluated: plant height, grain weight, grains per area and yield (Table 2). According to the water balance of the experiment period (Figure $2 a$ and $2 b$ ), the amount of water available during soybean cultivation for the crop was sufficient, with no periods of stress. This may have contributed to have had no difference among treatments 
Table 2. Plant height (PH), grain weight (OGW), grains per $\mathrm{m}^{2}$, and yield $(\mathrm{Y})$ of soybean sown on different conditions of residual biomass in Jataí, Goiás, Brazil.

\begin{tabular}{lllll}
\hline Residual biomass & $\mathrm{PH}(\mathrm{cm})$ & $\mathrm{GW}(\mathrm{mg})$ & $\mathrm{Grain} \mathrm{m}^{-2}\left(\mathrm{n}^{\circ}\right)$ & $\mathrm{Y}\left(\mathrm{kg}_{\mathrm{ha}} \mathrm{ha}^{-1}\right)$ \\
\hline Sorghum & 54 & 120.5 & 2723 & 3,281 \\
Sorghum + Palisadegrass (0 DAS ) & 57 & 122.1 & 2578 & 3,148 \\
Sorghum + Palisadegrass (15 DAS) & 54 & 119.2 & 2649 & 3,158 \\
Sorghum + Palisadegrass (25 DAS) & 53 & 123.4 & 2675 & 3,301 \\
Palisadegrass (0 DAS) & 57 & 120.5 & 2709 & 3,264 \\
Palisadegrass (15 DAS) & 57 & 121.9 & 2598 & 3,167 \\
Palisadegrass (25 DAS) & 56 & 121.8 & 2616 & 3,186 \\
\hline 1- DAS: days after sorghum. & & & &
\end{tabular}

As it is residual biomass of grasses, which have high $\mathrm{C}: \mathrm{N}$ ratio, the nutrients mineralization effect in this residual biomass was not evident in the first soybean crop cultivated in succession. Possibly there could be some difference if there were a greater time gap, for example, more time for dry biomass decompose and mineralize.

Other works that tested different types residual biomass in soybean, cultivated only one growing season also did not find differences in soybean plant development and yield (Almeida et al., 2008; Oliveira et al., 2013).

However, in work which evaluated two consecutive growing seasons, there was increase in soybean yield on treatment with higher residual dry matter (Sodré Filho, 2013). The presence of residual dry biomass for the summer crop can provide better growing conditions, because it retain more soil moisture and thermal protection against direct incidence of sunlight on the ground. These conditions are important especially for a tropical environment, like brazilian cerrado conditions, which is subject to high temperatures and periods of drought.

Despite not having been evaluated in this study, there are reports that palisadegrass contributes to soil physical quality, because develop a dense root system, which favors an increased soil porosity and incorporation of organic matter in the subsoil (Kluthcouski et al., 2000; Silva et al., 2007), also in the weed control (Braz et al., 2006; Correia et al., 2007).

\section{Conclusions}

Concomitant sowing of sorghum and palisadegrass reduced sorghum grain yield, however when palisadegrass sown was carried out 15 days after, did not affect sorghum grain yield.

The palisadegrass biomass production reduced when intercropped with sorghum, but biomass of sorghum-palisadegrass intercropping was superior to sorghum in monoculture.

Soybean yield did not differ among treatments when grown on different straws in the first year of cultivation.

\section{Acknowledgement}

We acknowledge funding from the São Paulo Research Foundation, grant n'. 2016/06310$0 . "$

\section{References}

Almeida, V.P., Alves, M.C., Silva, E.C., Oliveira, S.A. 2008. Rotação de culturas e propriedades físicas e químicas em latossolo vermelho de cerrado sob preparo convencional e semeadura direta em adoção. Revista Brasileira de Ciência do Solo 32: 1227-1237.

Almeida, C.M., Lana, A.M.Q., Rodrigues, J.A.S., Alvarenga, R.C., Borges, I. 2012. Influência do tipo de semeadura na produtividade do consórcio sorgo-Urochloa brizantha $\mathrm{cv}$. marandu no sistema de integração lavoura-pecuária. Revista Brasileira de Milho e Sorgo 11: 60-68.

Alves, V.B., Ceccon, G., Leite, L.F. 2013. Morfologia e produtividade de híbridos de milho safrinha solteiro e consorciado com braquiária. Revista Brasileira de Milho e Sorgo 12: 152-163.

Araujo, L. C. D., Santos, P. M., Mendonça, F. C., Lima, N. R. C. D. B. 2011 . Development of maize and palisadegrass plants cultivated in intercrop under water deficit. Revista Brasileira de Zootecnia 40: 1397-1404.

Baldé, A. B., Scopel, E., Affholder, F., Corbeels, M., Da Silva, F. A. M., Xavier, J. H. V., Wery, J. 2011. Agronomic performance of no-tillage relay intercropping with maize under smallholder conditions in Central Brazil. Field Crops Research 124: $240-251$.

Borghi, E., Costa, N.V., Crusciol, C.A.C., Mateus, G.P. 2008. Influência da distribuição espacial do milho e da Brachiaria brizantha consorciados 
sobre a população de plantas daninhas em sistema plantio direto na palha. Planta daninha 26: 559-568.

Braz, A.J.B.P., Procópio, S.O., Cargnelutti Filho, A., Silveira, P.M., Kliemann, H.J., Cobucci, T., Braz, G.B.P. 2006. Emergência de plantas daninhas em lavouras de feijão e de trigo após o cultivo de espécies de cobertura de solo. Planta daninha 24: 621-628.

Burt, R. \& Soil Survey Staff. 2014. Soil survey investigations report no. 42, version 5.0. In Kellogg Soil Survey Laboratory Methods Manual. U.S. Department of Agriculture, Natural Resources Conservation Service, Lincoln, USA.

Conab - Companhia Nacional de Abastecimento. Produtos e serviços - indicadores da agropecuária. 2016. http://www.conab.gov. br/<Access on 2 Feb. 2016>

Correia, N.M., Durigan, J.C., Klink, U.P. 2007. Influência do tipo e da quantidade de resíduos vegetais na eficácia de herbicidas aplicados em pré-emergência na cultura da soja. Bragantia 66: $111-120$.

Crusciol, C.A.C., Mateus, G.P., Pariz, C.M., Borghi, E., Costa, C., Silveira, J.P.F. da. 2011. Nutrição e produtividade de híbridos de sorgo granífero de ciclos contrastantes consorciados com capim-marandu. Pesquisa Agropecuária Brasileira 46: 1234-1240.

Embrapa. Centro Nacional de Pesquisa de Solos. 2013 (a). Sistema brasileiro de classificação de solos. $3^{a}$ ed. Embrapa, Rio de Janeiro, Brasil. 353p.

Embrapa. Centro Nacional de Pesquisa de Soja. 2013 (b). Tecnologias de Produção de Soja - Região Central do Brasil 2014. Embrapa, Londrina, Brasil. 265p.

Freitas, G.A., Sousa, C.R., Capone, A., Afférri, F.S., Melo, A.V., Silva, R.R. 2012. Adubação orgânica no sulco de plantio e sua influência no desenvolvimento do sorgo. Journal of Biotechnology and Biodiversity 3: 61-67.

Horvathy Neto, A., Silva, A.G., Teixeira, I.R., Costa, K.A.P., Assis, R.L. 2014. Consórcio de sorgo granífero e braquiária na safrinha para produção de grãos e forragem. Revista Caatinga 27: 132141.

Inmet - Instituto Nacional de Meteorologia. Banco de Dados Meteorológicos para Ensino e Pesquisa. 2016. http://www.inmet.gov.br/ portal/<Access on 2 Feb. 2016>

Kluthcouski, J., Cobucci, T.; Aidar, H., Yokoyama, L.P., Oliveira, I.P., Costa, J.L.S., Silva, J.G., Vilela, L., Barcellos, A.O., Magnabosco, C.U. 2000. Circular Técnica 38 - Sistema Santa Fé. Embrapa Arroz e
Feijão, Santo Antônio de Goiás, Brasil. 28 p.

Lima, N. R. C. B., Santos, P. M., Mendonça, F. C., Araujo, L. C. D. 2011 . Critical periods of sorghum and palisadegrass in intercropped cultivation for climatic risk zoning. Revista Brasileira de Zootecnia, 40: 1452-1457.

Magalhães, P.C., Durães, F.O.M., Rodrigues, J.A.S. 2009. Cultivo do sorgo: ecofisiologia. In: Rodrigues, J.A.S. (ed.) Cultivo do sorgo. Embrapa Milho e Sorgo, Sete Lagoas, Brazil. http://www. cnpms.embrapa.br/publicacoes/sorgo_4_ed/ ecofisiologia.htm/<Access on Mar. 2014>

Mateus, G.P., Crusciol, C.A.C., Borghi, E., Pariz, C.M., Costa, C., Silveira, J.P.F.da, 2011. Adubação nitrogenada de sorgo granífero consorciado com capim em sistema de plantio direto. Pesquisa Agropecuária Brasileira 46: 1161 1169.

Munz, S., Graeff-Hönninger, S., Lizaso, J. I., Chen, Q., Claupein, W. 2014. Modeling light availability for a subordinate crop within a strip-intercropping system. Field Crops Research 155: 77-89.

Oliveira, P., Nascente, A.S., Kluthcouski, J. 2013. Soybean growth and yield under cover crops. Revista Ceres 60: 249-256.

Pacheco, L.P., Pires, F.R., Monteiro, F.P., Procopio, S.O., Assis, R.L., Carmo, M.L., Petter, F.A. 2008. Desempenho de plantas de cobertura em sobressemeadura na cultura da soja. Pesquisa Agropecuária Brasileira 43: 815-823.

Rolim, G.S.; Sentelhas, P.C.; Barbieri, V. 1998. Planilhas no ambiente Excel para os cálculos de balanços hídricos: normal, sequencial, de cultura e de produtividade real e potencial. Revista Brasileira de Agrometeorologia 6:133-137.

Santos, G.G., Silveira, P.M., Marchão, R.L., Becquer, T., Balbino, L.C. 2008. Macrofauna edáfica associada a plantas de cobertura em plantio direto em um latossolo vermelho do Cerrado. Pesquisa Agropecuária Brasileira 43: 115-122.

Silva, A.C. da, Freitas, F.C., Ferreira, L.R., Freitas, R.S. 2006. Dessecação pré-colheita de soja e Brachiaria brizantha consorciadas com doses reduzidas de graminicida. Pesquisa Agropecuária Brasileira 41: 37-42.

Silva, A.G. da., Mores, L.E. de., Horvathy Neto, A., Teixeira, I.R., Simon, G.A. 2013. Consórcio na entrelinha de sorgo com braquiária na safrinha para produção de grãos e forragem. Semina: Ciências Agrárias 34: 3475-3488.

Silva, M.B., Kliemann, H.J., Silveira, P.M., Lanna, A.C. 2007. Atributos biológicos do solo sob influência da cobertura vegetal e do sistema 
Dias et al. (2018) / Sowing date of palisadegrass intercropped ...

de manejo. Pesquisa Agropecuária Brasileira 42: 1755-1761.

Silva, R.N.O., Arnhold, E., Araújo, B.L., Oliveira, G.H.F., Costa, J.R.S., Oliveira Junior, E.A., Lima, C.F. 2010. Comportamento Agronômico de cultivares de sorgo granífero avaliados em safrinha. Revista Trópica - Ciências Agrárias e Biológicas 4: 39-43.

Sodré Filho, J. 2013. Consórcio sorgo graníferobraquiária: fitomassa, dinâmica de plantas daninhas e rendimento da soja em sucessão. 207p. (D.Sc. Thesis) - Universidade de Brasília - Faculdade de Agronomia e Medicina Veterinária, Brasília, Brazil.

Thorntwaite, C.W.; Mather, R.J. The water balance. New Jersey: Laboratory of Climatology, 1955. 104p. (Publications in Climatology, 8). 